\title{
Composing Conventions: The First Universal Aspect of Moda-De-Viola
}

\author{
Jean Carlo Faustino \\ Federal University of Sao Carlos, Brazil
}

Copyright $\subset 2017$ by authors, all rights reserved. Authors agree that this article remains permanently open access under the terms of the Creative Commons Attribution License 4.0 International License

\begin{abstract}
This article aims to address the song-form of moda-de-viola: a music genre considered genuinely Brazilian and of rural origin; however, it was disseminated by the record industry throughout the twentieth century. The issue will be addressed by analyzing the constituent elements of this musical genre, which was based on a bibliographical review of authors who have systematically studied the topic, which was in contrast to studies conducted by the author of this article. So, the exposition of this analysis will be accomplished by revealing the elements that are necessarily present in every moda-de-viola, followed by those elements which eventually appear on compositions. This exposition will, however, be preceded by an introduction that seeks to contextualize the relevance of this reflection for the study of moda-de-viola itself. This argument is readdressed in the final considerations of the article, which looks forward to presenting new research possibilities suggested (or reopened) by this reflection, followed by a brief overview of what was previously present.
\end{abstract}

Keywords Form, Musical, Moda-De-Viola, Caipira Music, Brazil

\section{Introduction}

In November 2015, I had the opportunity to present some partial results of a work that I had developed as a research visitant in the Department of Spanish, Portuguese and Latin American Studies of King's College London.

This occurred during the Latin American Music Seminar, which was set up by Institute of Latin American Studies and by the Institute of Musical Research of the 'School for Advanced Study' of The University of London. At such event, that took place on the 7th of November in London Senate House, my presentation addressed the Rules of Composition for modas-de-viola: a rural Brazilian song-form and, as the title suggests, it aimed to outline the conventions used by the composers of a typical Brazilian genre known as moda-de-viola.
This article corresponds to the extended content of such presentation and also details some important aspects that could not be mentioned accordingly due to notorious time limitations, but were essential to provide credibility and support to the arguments there presented. Moreover, this article incorporates some improvement suggestions as well, which were provided to me by some experts in Latin-American music, who had attended such event, to whom I am very grateful.

As follows, this article aims to present the song-form moda-de-viola through a structural model that present their constitutive elements in a didactic manner, which facilitates its comprehension by the international public to which this music genre (typical of central southern Brazil), is unknown, at least until now.

The way this structural model was elaborated will be addressed later in this article. Until then, however, it is worth emphasizing the context to which this reflection belongs to: the search for universal aspects in moda-de-viola. Initially this research was linked to the hypotheses that the narratives presented in the lyrics of the compositions of this music genre comprised humanistic elements that belonged to other literature narratives in general as well. However, this dynamics of research ended up conducting me to a very unpredictable and surprising path: that of which the universal can be found in what is specific, that is, within the rules used by the composers of such deeply rooted Brazilian music genre.

Thus, this is the broadest context to which this reflection belongs to, which encompasses the following theoretical presumptions: every music genre has its own rules or formal conventions that are used by composers who take them into consideration in order to get legitimate response from the public. Consequently, this was the first universal aspect of moda-de-viola, whose comprehension I was able to develop and share with the audience at the Latin American Music Seminar and now take the chance to reveal in this article.

\section{Consciousness \& Legitimacy}

Moda-de-viola is a genuine Brazilian style of music that 
has something very unique as well as universal: that is its composing conventions. Unique because they are solely applied to compositions regarding this music genre; and universal because the fact of having such conventions integrates it to other music genres, which have likewise their own conventions.

Therefore, the objective of this article is to explain these composing conventions. The content to be presented corresponds to part of an ongoing research in King's College, addressing the universal principles of moda-de-viola, which has been accomplished as research visitant.

In order to comprehend and, consequently, explain the composing conventions of moda-de-viola, I have combined analytical hearings to the work of other authors who have dedicated themselves to systematically analyze the structural elements in moda-de-viola. The results of such confrontation, in addition to the examples that illustrate every element, correspond to the content of this article.

Before pointing out the elements that constitute moda-de-viola, which correspond to the aspect that every composer must consider when elaborating a new moda, it is worth understanding the relevance of such issue when studying moda-de-viola. Such relevance may be comprehended for instance by observing one of the first reflections on the form of the moda-de-viola in which Mário de Andrade affirms:

Caipiras confidently distinguish a moda.

It distinguishes itself from others for it is a retelling of a tale more or less sensational, or of an important event of the routine told a story. Thus, it is considerably rare that a legitimate caipira singer sings a moda in a series of four-verse-strophes ${ }^{1}$. (ANDRADE, 1989, p. 342-343)

The first aspect that draws our attention in the aforementioned definition is the one in which Mário de Andrade says that the legitimate caipira, that is the peasant who lives in the southern east of Brazil, precisely identifies a moda-de-viola. This is the first relevant aspect for this study, which is directly correlated to the objective of this article: the legitimacy among the public. Thus, one who may dedicate itself to the composition of a new piece of moda-de-viola was aware that the public recognized the genre. Without public legitimacy there would be no recognition whatsoever; consequently no success.

Another important aspect in this definition regards the part in which the author says that it would be "extremely rare that a legitimate country singer (caipira) sings as a moda, which is a series of four-verse-strophes." (ANDRADE, 1989, p. 342-343). Notice that the legitimacy issue is evident here. However, this time applied to the interpreter of a moda-de-viola who, according to the author, knew what was

\footnotetext{
${ }^{1}$ Original text: $\mathrm{O}$ caipira distingue com certa firmeza o que seja uma moda. $\$ Esta se distingue por ser o reconto dum caso qualquer mais ou menos sensacional, ou dum fenômeno importante da vida quotidiana, historiado. Assim, é bem raro que um cantador caipira legítimo cante como sendo uma moda uma série de quadras soltas. (ANDRADE, 1989, p. 342-343)
}

singing when interpreting a song of this music genre. It is assumable that the interpreter knew (or should know) the conventions of interpretation of a moda-de-viola and that a composer was supposed to be acquainted with them.

Nothing but the lyrics of some moda-de-viola would best reveal the consciousness that both the composers and the interpreters had over the necessity to learn (and embody) composing conventions regarding this music genre. See for instance the song Padecimento, which was recorded by TiãoCarreiro e Pardinho. Following the first two strophes, in which the narrator talks about unfortunate love adventures and also how being a violeiro (ten-string viola player) helps him overcome his sadness. He mentions his abilities to compose "happy and sad moda whenever convenient", which evidences that he knows how to handle the necessary elements to provoke happiness and sadness within those who listen to them.

In this strophe, he also affirms that many people wish to have such a talent, but they do not. However, he considers it "a gift from God". It is known, with regards to the work of Norbert Elias (1994) on Mozart, that this idea of a gift often obscures a learning process, as well as knowledge and dedication demanded from the musician in order to develop the ability to manipulate well the music elements of a specific time and environment to which it belongs.

And, in the last strophe of the moda Padecimento, the narrator explains how he learned to play viola caipira and to compose modas-de-viola:

Then, in order to learn how to sing along with the viola, the first study I had

I have learned with an old violeiro that used to compose impossible moda

Consequently, I am a new violeiro, but I also want to be $\operatorname{mad}$

I compose moda of good people and of uncorrectable ones

Every moda that I invent include ruler, lever and plum line.

Then, thinking carefully, a violeiro really enjoys his life $^{2}$

It is noticeable that the narrator learned how to sing viola as an old violeiro who used to compose "impossible moda", which meant sophisticated modas that would impress listeners with his ability to do what seemed impossible for many people.

This reveals the traditional method of transmitting skills in a master disciple relationship. But, the fact is that he had to learn with someone that knew how to compose - someone that knew the conventions of composition for moda-de-viola. And now, after learning with an old violeiro, he does different compositions making exclusively use of "ruler, lever and plum line". This is, therefore, an expression that

\footnotetext{
2 Original text: Ai, pra aprender cantar de viola, primeiro estudo que eu tive, $\$ Aprendi com um violeiro velho que fazia moda impossível $\backslash \backslash$ Pois, eu sou um violeiro novo, mas também quero ser terrível $\backslash \backslash$ Faço moda de gente boa e de algum incorrigível $\backslash \backslash$ Toda moda que eu invento ocupo régua, prumo e nível $\backslash \mathrm{Ai}$, pensando bem, um violeiro com prazer no mundo vive
} 
plainly affirms that the ability to compose modas was the result of the development of specific elements that the narrator presents here. These elements allude to measurement instruments typical of civil construction, which back then was the professional sector that received many migrants coming from the rural country, who did not have the specific professional qualification of urban environments (DURHAM, 1973).

In another piece of moda called Minha Vida, also recorded by the duo Tião Carreiro e Pardinho, the narrator is pride of his ability to compose modas, renewing his repertoire when the audience got bored of the old songs.

Compose good modas when the public is bored Compose "modas dobradas" and very picked To avoid difficult situation in the parties ${ }^{3}$

However, in contrast with the previous moda, he mentions the structural elements of the moda-de-viola without making use of any analogy. In certain moments, he explicitly mentions the modas dobradas, which corresponds to a specific strophe size: the double of the basic strophe.

This same element, with a different name though, appears in a different composition: Consagracão, which was also recorded by the duo Tião Carreiro e Pardinho. In this piece, the narrator says that another violeiro challenges him to sing a moda of double verse; that is, a moda dobrada.

I was asked to sing a doubled verse

I played deftly repicado on the viola

I saluted the host and all the guests ${ }^{4}$

Another element of composition emphasized in lyrics of this moda is repique. In the aforementioned lyrics, the narrator says that the violeiro played "deftly repicado on the viola"; that is, he played repique on the viola. Notice that in a single moda it is possible to realize the presence of two structural elements of the genre: the doubled verse and the repique.

There would also be some other examples that could be used here to evidence this consciousness regarding the structural elements of a moda-de-viola and its correlation to composing conventions. However, a final element is enough for now, which will also be the end of the introduction and the prelude for the next topic: the moda Gato de Três Cores.

After mentioning, in the first strophe, the invitation the narrator received to play in a Corpus Christ, in the second strophe he depicts the impact of repique on his viola:

We got to this party and the gate banged

A happy man welcomed me

There inside there were many of his folks

Immediately served with distilled alcohol and I drank it

My old chest suddenly thrilled

\footnotetext{
${ }^{3}$ Original text: Fazer modas boas $\backslash$ Quando o povo enjoa $\backslash$ Fazer modas dobradas $\backslash E$ bem selecionadas $\backslash$ Pras festas que for $\backslash$ Não passar calor

${ }^{4}$ Original text: Me pediu que eu cantasse um verso dobrado $\backslash$ Bati a viola bem repicado $\backslash \backslash$ Saudei o festeiro e todos os convidados
}

I played repique in the pinho and the strings moaned I called the party maker, he attended me

Let's go to the living-room as time has been victorious $^{5}$

The first interesting aspect in the lyrics of this moda-de-viola, within the context of this article, is that it cited one specific element, which holds the same name that Rafael Garcia (2001) observed: repique. In these lyrics, the composer transforms the adjective repique into a verb, which is unfortunately missed in this translation in English: "I played repique in the pinho and the strings moaned". Pinho alludes to the country guitar (viola caipira), referring to the wood that is traditionally used to graft a viola, as well as other musical instruments.

Another interesting aspect found in the lyrics of such moda is the description of the context and the effects of the repique. The context is the performance of a violeiro in a party and, consequently, the expectation that the public held when listening to his modas. The use of repique is equivalent to that of the modas-de-viola, which was recorded: the beginning of everything; that is, the announcement that a moda is coming next.

Lastly, the effect that can be observed in the verse "the strings moaned", which corresponds to a sort of symbolic representation of the effect caused by the repique, which is able to convince the violeiro that the time of challenging another player has arrived and that he was ready for it.

Here is another clear example of the knowledge that such composers and interpreters were expected to have regarding the structural elements in order to reach the objective, enabling not only the success and the recognition of the moda but also the grasping of the narrative.

\section{Repique \& Recortado}

Moda-de-viola is essentially composed of two parts: one is the singing part, which is always performed in duets; and another instrumental, which is played in the country guitar called, in Brazil, viola caipira. Actually, the viola is an essential instrument in moda-de-viola, as suggested the name of this music genre: where "moda" alludes to a kind of music that tells a story; and "de-viola" suggests that the song is followed by the viola caipira.

The viola caipira is an instrument that came from Europe, but underwent adaptations in Brazil, particularly regarding the tuning, which gives certain identity and authenticity to the so-called música caipira, of which the moda-de-viola is a music sub-genre. The following picture illustrates one typical viola used in the interpretation of the modas-de-viola.

\footnotetext{
${ }^{5}$ Original text: Chegamos na festa que o portão bateu $\backslash \backslash \mathrm{O}$ festeiro alegre me recebeu $\backslash$ Lá pra dentro estava uns amigos seus $\backslash \backslash$ Já veio uma pinga, tudo ali bebeu $\backslash \backslash$ Meu peito velho já desenvolveu $\backslash \backslash$ Repiquei no pinho que as cordas gemeu \\Chamei o festeiro, ele me atendeu \ "Vamos lá pra sala que a hora venceu"
} 


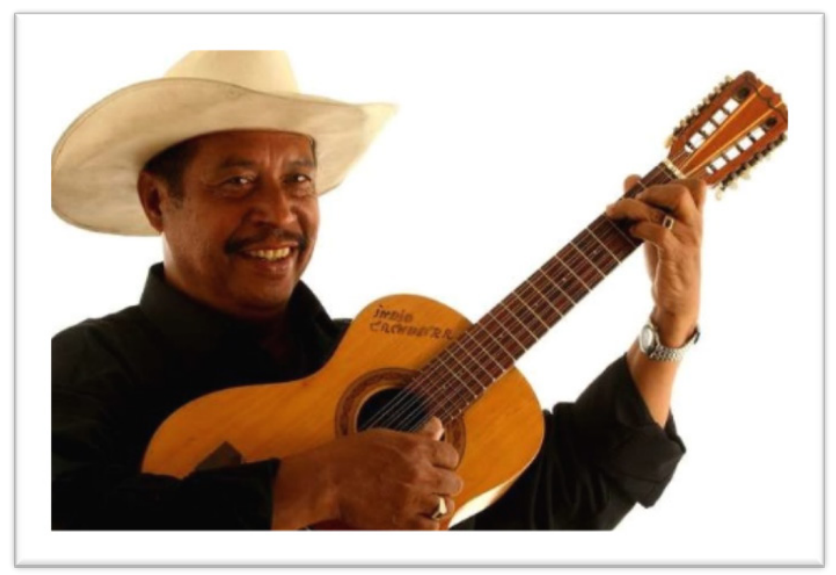

Figure 1. Viola caipira and the violeiro índio Cachoeira

A moda-de-viola always starts with an instrumental part, which precedes the singing part. This instrumental part is call repique or recortado, and its presence, before the first strophe and between other strophes, correspond to the first mandatory element in moda-de-viola.

Resulting from the combination of chords played on a typical rhythmic figure, the repique (or recortado) in the beginning of a moda-de-viola draws the attention of the listeners to the beginning of the singing part. This can be observed in the following figure, which corresponds to the transcription of the moda Boiadeiro Punho de Aço, transcribed by Rafael Garcia.

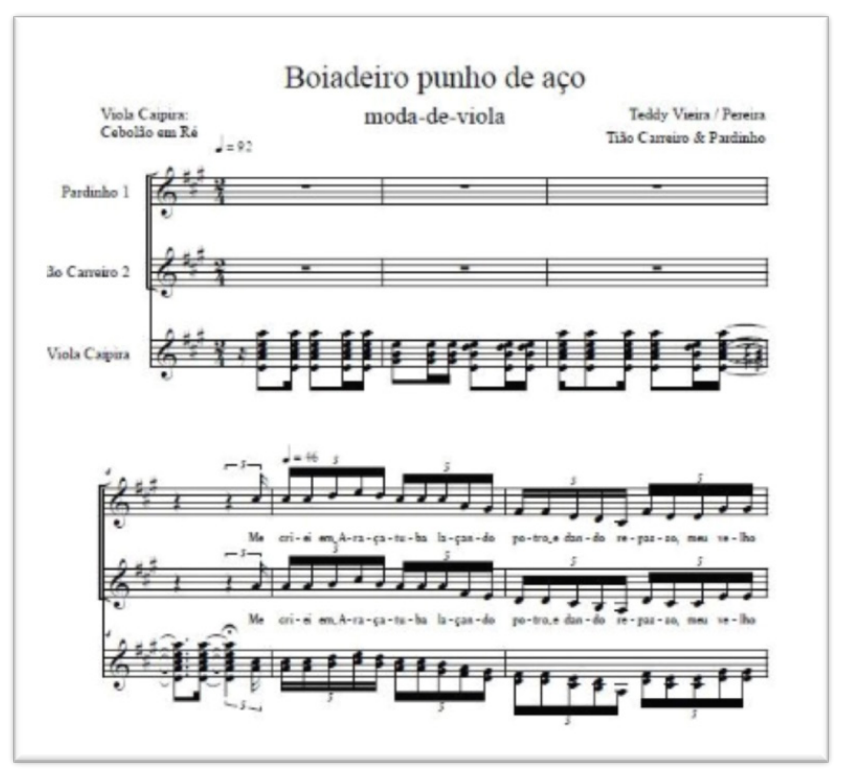

Figure 2. Transcription of moda Boiadeiro Punho de Aço, done by Rafael Garcia

In this figure, the first two lines correspond to the voices of the singers while the third correspond to the viola caipira. The repique/recortado occupies the first four compasses of the moda and its end presents the beginning of the duet singing.

Sometimes, the initial recortado is similar to the recortado played between the strophes as showed in the following figure, which corresponds to the same moda Boiadeiro Punho de Aço mentioned before.

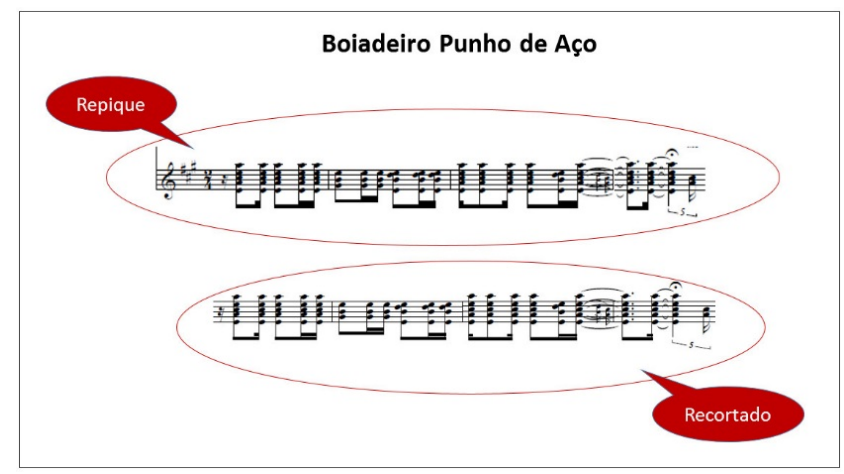

Figure 3. The two recortados in the moda Boiadeiro Punho de Aço

And as well as the initial recortado that draws the attention of the listener to the beginning of the song, the recortado between the strophes also has a specific function. They create a sort of suspense in the narrative, that is interrupted in specific moments by this instrumental part, that also enables the listener to assimilate what is narrated in the strophes (SANT'ANNA, 2000) (GARCIA, 2011).

Therefore, the essential parts for every moda-de-viola are assorted according to a diagram, presented in the following figure, in which the recortado announces the singing part, which is divided in strophes that are always intercalated by a second recortado.

So far the considerations were based on the analyzes that I carried out during my Phd research, as well as on the observation of Rafael Garcia (2011), which were made during some research that he accomplished for his master degree, that specifically addressed the analyzes of the structure of such music genre.

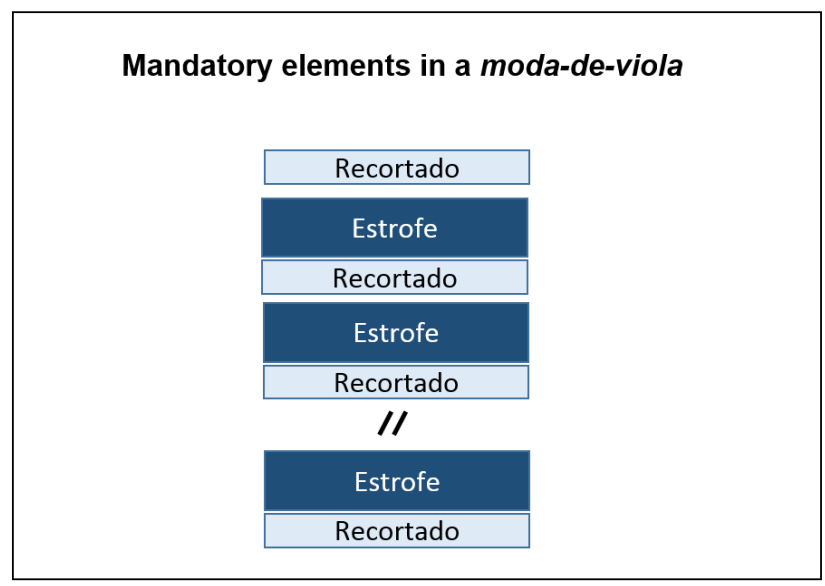

Figure 4. Basic structure of a moda-de-viola

In this research, Garcia has created a division that I also adopt in this article and that corresponds to the division of these structural elements; that is, between the mandatory ones that are found in every moda-de-viola and those that occasionally appear in some compositions. Here, in this 
topic, I showed the mandatory elements. But, before starting the explanation of the optional elements, in the next topic, I will better explain the singing part.

\section{Recitative Singing}

In theory, there are no moda-de-viola without repique and recortado, which were previously addressed. Likewise, there are no moda-de-viola without singing, which was called recitative (ANDRADE, 1989) since the first systematic analyzes of such music genre carried out by Mario de Andrade in the beginning of $20^{\text {th }}$ century, who said that this singing part submits (and sometimes subverts) the rest of the song. It submits because every element of a moda-de-violaseems to exist in order to call the attention to the story narrated by the singing part; and it subverts because the time and the metric of the song are often suspended and subdivided in favor of the drama of the narrative revealed in the lyrics.

Another author that observed this preponderance of the singing was Alex Dent:

"Moda de viola, by contrast, has no choruses, so that the alternation between eight-line (or nine-line) verses and seven-line verses is what marks progress. In terms of musical form therefore, an evening performance goes back and forth between one or the other form of communicative practice, providing the structuring principle of the passage of time. In one modality, time unfolds according to a prescribed beat throughout the song. In another, the passage of time unfolds according to the words, with musical pauses and starts following from those words." (DENT, 2009, p. 208)

However, despite the subversion, the recitative singing generally happens within very strict conventions. First of all, there is no chorus in moda-de-viola. Instead, the entire singing part is divided in strophes with the same number of lines. Lines are formulated in sentences with a number of syllables, which follow a common regularity.

Moreover, the singing of such strophe happens according to the melody that repeats itself equally in every strophe. Melody is repeated by double voices according to a specific harmonic interval that usually is of thirds and sixth. This same melody of the singing is also repeated in a ponteado done on the viola caipira during the singing as if it were a third voice.

Notice, for instance, the size of the strophes in lines and the latter divided in syllables following the rhyme. The following picture aims to highlight the metrics along an entire piece of moda-de-viola. The example selected is the same moda whose transcription was mentioned previously in this article: Boiadeiro Punho de Aço.

This figure shows the number of each line; the bars "/" indicate syllable separation; the parenthesis "( )" indicate the number of syllables of each verse; and the yellow highlights evidence the rhyme parts.

\section{Boiadeiro Punho-de-aço \\ Interpretação de Tião Carreiro e Pardinho}

\begin{tabular}{|c|c|c|}
\hline & Me /cri/ ei em/ A/ra/ça/tu/ba & (7) \\
\hline 2. & $\mathrm{La} / \mathrm{ccan} / \mathrm{do} / \mathrm{po} / \mathrm{tro}$ e/ dan/do/ re/pas/so ${ }^{1}$ & (9) \\
\hline & Meu/ve/lho/ pai,/ pra/li/dar/com/boi, & \\
\hline & Des/de /pe/que/no/gui/ou/meus/pas/so & \\
\hline 5 & Meu/fi/lho, o/mun/do é /uma es/tra/da & \\
\hline & Chei/a/ de a/tai/o e /tan/to em/ba/ra/ço & \\
\hline 7. & Mas,/se/ vo/cê /for/ bom /no /ci/pó & \\
\hline 8. & $\mathrm{Na} / \mathrm{vi} / \mathrm{da} / \mathrm{nun} / \mathrm{ca}$ /te/rás/ fra/cas/so & \\
\hline & Com /vin/te /a/nos /par/ti, & \\
\hline & foi /na/ co/mi/ti/va /de um /tal l/ná/cio & \\
\hline 3. & Sen/ti /um/ nó /me a/per/tá à /gar/gan/ta & \\
\hline 4. & Quan/do/ meu/ pai/ me /deu /um /a/bra/ço & \\
\hline 5. & Meu /fi/lho,/ Deus /lhe a/com/pa/nhe, & \\
\hline & São/ es/ses-os /vo/tos/ que eu /lhe/ fa/ço & \\
\hline & $\mathrm{E} / \mathrm{co} / \mathrm{mo} / \mathrm{prê} / \mathrm{mio} / \mathrm{do} / \mathrm{teu} / \mathrm{ta} / \mathrm{len} / \mathrm{to}$, & \\
\hline 8. & Lhe/ pre/sen/teio/ com-es/se/meu/la/ço & \\
\hline 1. & Por/ es/te /Bra/sil/a/fo/ra & \\
\hline 2. & $\mathrm{Fiz} / \mathrm{co} / \mathrm{mo} / \mathrm{faz}$-as/nu/vens/no/ es/pa/ço & \\
\hline 3. & Va/guei/ ao/léu/ co/nhe/cen/do/ ter/ras & \\
\hline 4. & Sem/pre/ga/nhan/do/ di/nhei/ro-aos/ma/ço & \\
\hline 5. & Meu/ci/pó em/ três/ ro/di/lhas & \\
\hline & $\mathrm{Co} / \mathrm{bria}$ a/ an/ca/ do/ meu/ pi/ca/ço & \\
\hline & $\mathrm{Foi} / \mathrm{o} / \mathrm{que} / \mathrm{me} / \mathrm{ga} / \mathrm{ran} / \mathrm{tiu} / \mathrm{o} / \mathrm{no} / \mathrm{me}$ & \\
\hline & $\mathrm{De} / \mathrm{boi} / \mathrm{a} / \mathrm{dei} / \mathrm{ro} / \mathrm{pu} / \mathrm{nhos} / \mathrm{de} /$ aço & \\
\hline
\end{tabular}

1. $\mathrm{De} / \mathrm{vol} / \mathrm{ta} / \mathrm{pra} / \mathrm{mi} / \mathrm{nha} / \mathrm{ter} / \mathrm{ra}$,

2. Via/ja/va a $/ \mathrm{noi} / \mathrm{te} / \mathrm{com} / \mathrm{o} / \mathrm{mor} / \mathrm{ma} /$ ço

3. $\mathrm{Na} /$ qui/lo eu/to/pei/com-u/ma/ boi/a/da,

4. Bei/ran/do/ rio/ vi/nha/ pas/so a/ pas/so

5. Um/ gri/to/ de/ boi/a/dei/ro,

6. $\mathrm{Pe} / \mathrm{din} / \mathrm{do} / \mathrm{aju} / \mathrm{da} /, \mathrm{cor} / \mathrm{tou} /$ o-es/pa/ço

7. E-eu/vi /o /peão/ que/ i/a/ ro/dan/do,

8. Sal/tei/ $\mathrm{no} / \mathrm{rio} / \mathrm{com} / \mathrm{o} / \mathrm{meu} / \mathrm{pi} / \mathrm{ca} / \mathrm{ço}^{2}$

1. A/ cor/ren/te/za/ era/ for/te,

2. Ti/rei-o/ci/pó/da/chin/cha/ do/ma/cho

3. E/ pe/lo-es/cu/ro-[a]in/da/con/se/gui

4. La/çar/o/ peão/ por/um/ dos/ seus/ bra/ço

5. Ao/ tra/zer/e/le/na/ prai/a,

6. $\mathrm{Meu} / \mathrm{co} / \mathrm{ra} / c ̧ a ̃ o / \mathrm{se} / \mathrm{fez} / \mathrm{em} / \mathrm{pe} / \mathrm{da} /$ ço

7. Por/ um $/ \mathrm{mi} / \mathrm{la} / \mathrm{gre} /$ que/ Deus/ $\mathrm{man} / \mathrm{dou}$,

8. Sal/vei/ meu/ pai/ com/ seu/ pró/prio/la/ço

Figure 5. Verses (lines) and syllables of each strophe of moda Boiadeiro Punho de Aço 
As noticeable, the rhyme repeats itself along the entire moda, always at the same place. In addition, the moda has a fixed number of eight verses, which explain why it is called dobrada (duplicated). According to the authors that have addressed such topic, this a typical strophe size used in moda-de-violas, which, according to BERNADELI (1991), the most favorite among composers of the twentieth century.

Another aspect depicted on the previous figure is the number of verses that comprises the strophe and its respective number of syllables. As we can see, the strophes of the moda used as an example are composed of verses of seven syllables (the first and fifth verses) and nine syllables (other verses). Those are, therefore, compound or double strophes; however, whose metric remains the same along the entire moda. Such occurrences are not exceptions, but one constitutive elements of conventions in composition in moda-de-viola. The interruption of such metrics, as we can see in the topic, has its own conventions: the levante and the baixão.

The size of the strophe, either in number of verses or in number of syllables, is an aspect that was addressed by the majority of the authors that have dedicated themselves to systematically analyze moda-de-viola. Regarding this consensus, however, Mário de Andrade (1989) added the cases in which the modas appear with strophes of 3 and 10 verses; Amadeu Amaral (1948) of 6; Bernadeli (1981) of 2,
12, 14, 16, 9, 11 and 13; and Garcia (2011) of 5.

When it comes to the number of syllables, the consensus among authors are the verses composed of 5 and 7 syllables. To this consensus Zamboni (1987) has added the cases in which modas have 11 syllables; Bernadeli (1991) of 6, 8 and 10; and Garcia (2011) of 11 and 12 syllables. Curiously, however, is that the moda used here as example has a number of syllables that were not, apparently, observed by any of these authors: the one with 9 syllables.

Beyond that, as previously mentioned, the melody of the recitative singing is also regular. Thus, the example of the rhyme of the amount of verses and syllables in the verses, as well as the melody, also repeat equally every each strophe.

In the beginning of this topic, it was affirmed that the singing part occurs in voice duets, which is sung in intervals of thirds or sixths. Indeed, this is the general convention; but, as previously highlighted by Garcia (2011), this does not mean that such distance among voices remain continuously the same along the entire singing of a moda. An example of the dynamics of such voices in a moda-de-viola can be observed in the following figure, elaborated based on the transcription of the first strophe of the same moda Boiadeiro Punho de Aço.

The transcription used as reference to the following figure is the same as the one previously showed made by Rafael Garcia.

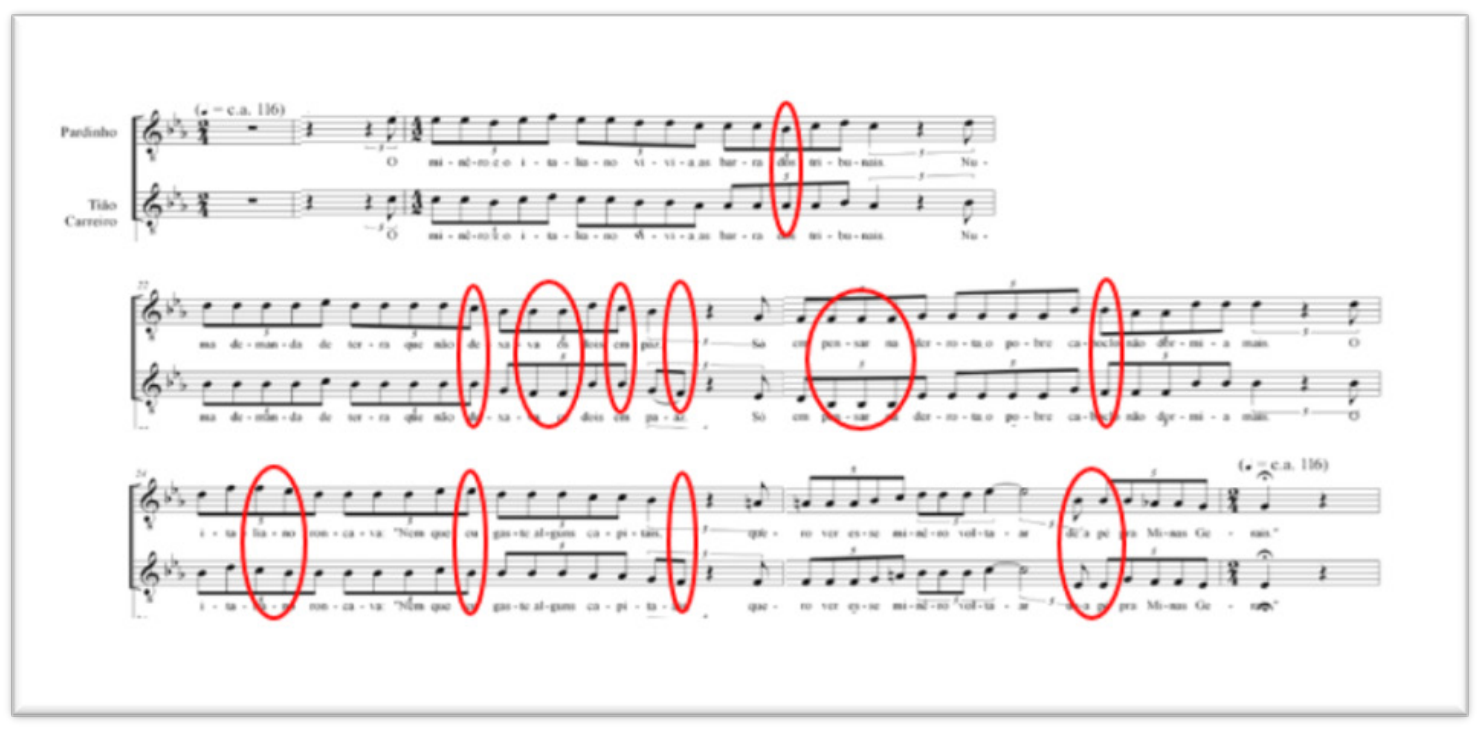

Figure 6. Singing part of the first strophe of moda Boiadeiro Punho de Aço 
Some modas are sung a cappella, limiting, consequently, the use of viola caipira during the singing. However, the viola caipira often follows the singing part by repeating (play ponteado), the same melody that is sung.

These elements, viewed until this point, are obligatory in all modas-de-viola. In the next topic, we will see other elements found only in some compositions of this genre music.

\section{Optional Elements}

As mentioned in the previous topic, the strophes in a moda-de-viola must always respect equal sizes. This is an aspect that may be observed right in the first strophe. This is a general convention and its interruption also has determined patterns: the levante and the baixão.

The majority of authors that carry out systematic analyzes on moda-de-viola point out the often presence of these two elements, which have, according to Maria Bernadeli (1991), only two verses. Even though this definition is not definitive, it is possible to say that the number of verses, either in baixão or in levante, is frequently smaller than the strophes of a moda-de-viola, which represents, consequently, an interruption of the metrics.

However, according to the analyzes performed by the authors that address this topic, as Amadeu Amaral (1948), Mário de Andrade (1989), Zamboni (1987), Garcia (2011) and Bernadeli (1991), levante may only appear before the first strophe whereas baixão is placed in the end of the moda. The reason why this convention is intimately related to the function is that they have.

- levante: draws the attention to the beginning of the singing narrative that is about start;

- baixão: draws the attention to the conclusion of the narrative sung by the recitative singing.

Concerning the two elements that appear occasionally in a moda-de-viola, Rafael Garcia (2011), in his master's degree research, has added other three elements: ponteado (also called ponteio), catira and declamation.

Ponteado correspond to a specific way of playing viola caipira, which is different from that used in the repique and recortado mentioned in the previous topic. More melodic than rhythmic (GARCIA, 2011, p.165), its sound highlights the singularity of the strings of the viola caipira, doubled in pairs, which corresponds to one single music note. However, one octave of difference and it occasionally appears in the introduction of some modas-de-viola as, for instance, the song $O$ Mineiro e O Italiano, which was also recorded by the duo Tião Carreiro e Pardinho.

The declamation is another occasional element in moda-de-viola, which is highlighted by Garcia (2011). It is not sung, but recited as a poem and, in contrast to the levante and baixão, there is no determined place for it to appear in a composition of the genre.

In my doctorate research, which was accomplished based on fifty modas-de-viola of the duo Tião Carreiro e Pardinho, only one presented a summary, which is herein addressed: the declamation. It is the song Boiada Cuiabana. Throughout his narrative, the story alludes to an episode of the life of a cowboy who, after leading the cattle to the state of Mato Grosso, meets a woman from Paraguay (country that borders the state of Mato Grosso) on the way back and he falls in love deciding to take her with him.

And, in the middle of the recitative song Boiada Cuiabana, there is a declamation before the last strophe, which also comprises a second declamation: the first one is the one that refers to the cowboy, who is the narrator of the story, whereas the declamation that surges is the beautiful Paraguayan lady, who declares his love to him. After that, in the last part of declamation, the narrator told:

The cowboys in the ranch were bound to go

On a perfumed rosebush, the birds sing

My donkey seemed to guess

That I would not leave alone

My love followed $\mathrm{me}^{6}$

The catira, the last optional element in a moda-de-viola, added Rafael Garcia, corresponds either to a type of rhythm. The following figure, taken from his master's degree dissertation (GARCIA, 2011, p.172), corresponds to the transposition of the song Eu Gosto composed by Luiz de Castro and Braz Aparecido and interpreted by the duo Vieira and Vieirinha. Its shows the rhythm of catira that combines recortado with clap hands and tap dance.

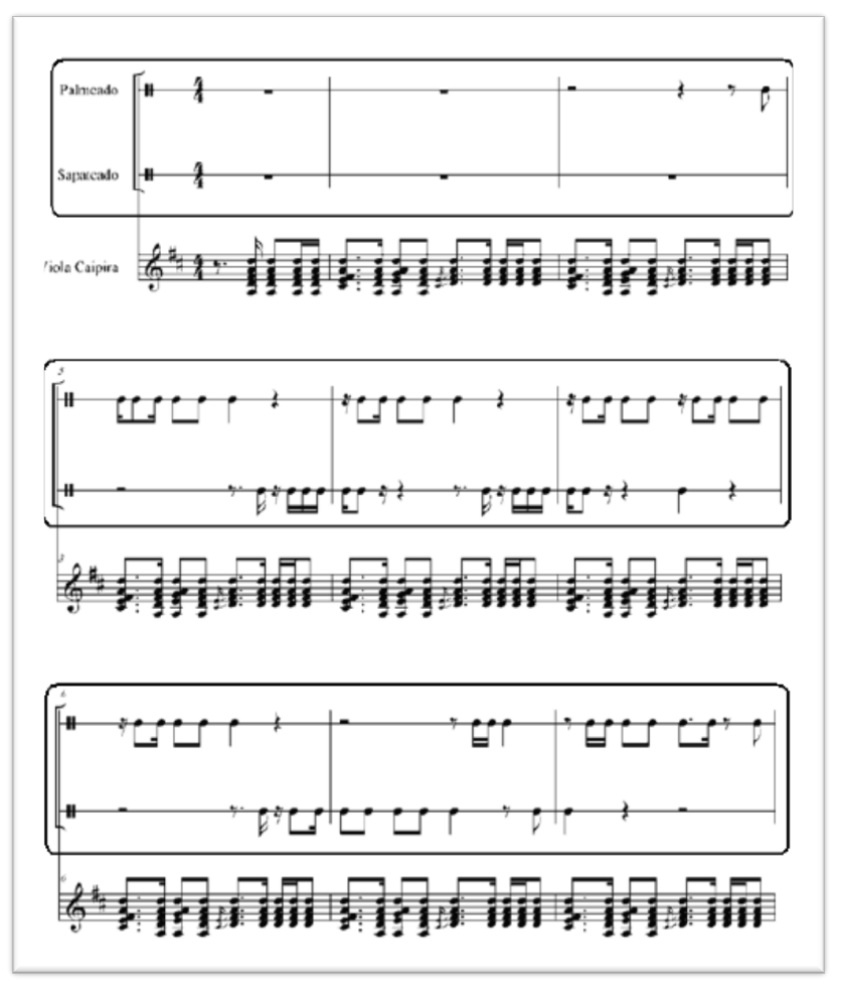

Figure 7. Music sheet of a rhythmic element of catira in moda Eu Gosto

So, more than a rhythmic beat, catira is a kind of dance,

${ }^{6}$ Original text: E os boiadeiro no rancho estavam prontos para a partida / Numa roseira cheirosa, os passarinhos cantava, / A minha besta ruana parece que adivinhava / Que eu sozinho não partia, / Meu amor me acompanhava 
whose performance cause grate dramatic impact in the rural context, particularly when the floor is made of wood. Catireiros, who used to dance catira, wore boots that hit the floor so strongly that it made this loud noise which filled the whole place. Thus, the presence of catira in the modas-de-viola used to have strong emotional appeal to the ears of the listeners, which would remind them of happy moments of celebration in the country.

Although there is an emotional appeal provoked by the rhythmic beat of the clap hand and foot tapping in a moda, catira does not overtake the recitative singing, what occurs only the intervals between strophes.

Briefly, the recitative singing, recortado are the obligatory elements that are present in every moda-de-viola; whereas baixão, levante, ponteado, declamation and catira are optional elements that may or may not be present in modas. The following figure shows schematically the position of all these aforementioned elements, indicating the mandatory ones in blues and the occasional ones in red:

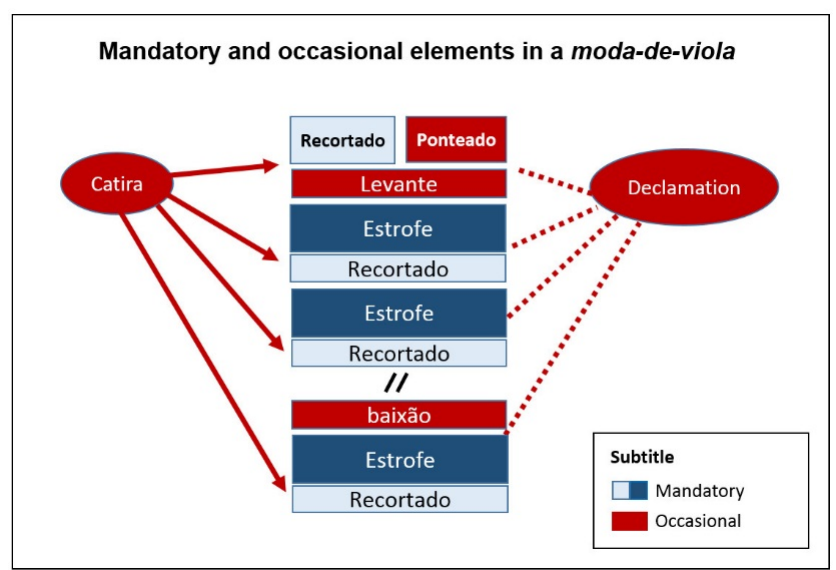

Figure 8. Mandatory and occasional elements in a moda-de-viola

\section{Final Considerations}

As addressed in this article, the structure of a moda-de-viola is composed of different elements that together define its musical form. Although such element may be occasionally found in other music genres, this unique combination is what defines a moda-de-viola, which might be reduced to a minimum combination of repique and recortado with recitative singing.

However, the simple presence of the elements addressed in this article does not guarantee the success of a moda-de-viola. Despite the legitimacy that such elements give to a composition, one important aspect is necessary to complete and provide meaning to the other, which is the narrative that takes place in the strophe.

In the article Moda-de-viola enquanto literatura: a quintessência da sabedoria caipira, I show that the narratives performed in moda-de-viola always tells a story

\footnotetext{
${ }^{7}$ Translation: The moda-de-viola as literature: the quintessence of caipira wisdom
}

that do not only refers to the social reality of the listener, which may be primarily composed of peasants, but also of literature.

Thus, the history of Brazilian peasants did not only reflect in the narrative of such modas but it also permitted the public to transcend the limitations imposed by their harsh reality. Furthermore, as common in literature, such narratives had the potential to educate the listener to life, which not only refers to the practical aspects, for instance regarding the society as well as professional and family issues, but also the humanization and the sensibility towards beauty.

However, analyzing the narrative is a very extensive accomplishment, which would demand another reflection. My doctorate thesis, for instance, addressed solely the narratives of one single duo of interpreters, applying a more sociological than a literature theory approach. In order to complement the sociological analyzes. I have started a research in King's College with purpose of readdressing the same object of research (modas-de-viola by Tião Carreiro e Pardinho) with a different perspective of analysis.

Thus, whereas the doctorate research has focused on the historical role and the regional aspects in which such moda-de-viola represented to the audience, the aim now is to comprehend the universal elements, which refer to narrative aspects that may be comprehended even if they were out of their historical context, as they are also found in general literature.

Initially, the purpose of this new ongoing research is to analyze such universal element found in the narratives of modas-de-viola by means of a comparative analysis, which may comprise some works of universal literature. However, the development dynamics of the research, primarily within the interactions with the research group of the Department of Latin American, Spanish and Portuguese Studies of the Art and Humanities Faculty of King's College, has drawn my attention to the element that I now consider as the first universal aspect, if not the most elementary among modas-de-viola: their conventions of composition.

The reflection developed in this article is not and does not aim to be the only regarding the conventions of composition in modas-de-viola. A complementary reflection of the narratives and its possible relation on the elements herein addressed are potential new topic to be developed. However, for the moment, the results here presented correspond to the first findings opened by new research perspectives and reflections. The evidence that the universal elements are often found among the most specific and unique.

Note: All songs mentioned in this article can be found and heard on YouTube.

\section{REFERENCES}

[1] AMARAL, Amadeu. Tradições populares. São Paulo: Instituto Progresso, 1948. 
[2] ANDRADE, Mário de. Dicionário musical brasileiro. Brasília, Belo Horizonte: Ministério da Cultura: Itatiaia, 1989.

[3] ARAÚJO, Alceu Maynard. Cultura popular brasileira. $2^{\mathrm{a}}$ edição. São Paulo: Melhoramentos, 1973.

[4] ARAÚJO, Alceu Maynard. Folclore nacional I: festas, bailados, mitos e lendas. $3^{\text {a }}$. edição. São Paulo: Martins Fontes. São Paulo, 2004.

[5] ARAÚJO, Alceu Maynard. Folclore nacional II: danças, recreação, música. São Paulo: Melhoramentos, 1964.

[6] ARAÚJO, Alceu Maynard. Folclore nacional III: ritos, sabença, linguagem, artes e técnicas. São Paulo: Melhoramentos, 1964.

[7] BERNADELI, Maria Madalena. A expressividade caipira em Vieira e Vieirinha. 1991. 217p. Dissertação (Mestrado em Letras) - Curso de Pós-graduação em letras, Universidade Estadual Paulista, São José do Rio Preto, 1991.

[8] DENT, Alex Sebastian. Country Critics: Música caipira and the Production of Locality in Brazil. Dissertation (Doctor of Philosophy) - Department of Anthropology. University of Chicago, 2003.

[9] DENT, Alex Sebastian. River of Tears: Country Music, Memory, and Modernity in Brazil. Durham: Duke University Press, 2009.

[10] DURHAN, Eunice. A caminho da cidade: a vida rural e a migração para São Paulo. São Paulo: Perspectiva, 1973.

[11] ELIAS, Norbert. Mozart: sociologia de um gênio. Tradução de Sérgio Goes de Paula. Rio de Janeiro: Editora Zahar, 1994.

[12] FAUSTINO, Jean Carlo. A moda de viola enquanto literatura: a quintessência da sabedoria caipira. In: Souza, Marly Gondim Cavalcanti; Silva, Agnaldo Rodrigues da (org.) Diálogo entre literatura e outras artes. Cáceres, MT: Ed. UNEMAT, 2014. p. 121-136.
[13] FAUSTINO, Jean Carlo. O Êxodo Cantado: a formação do caipira para a modernidade. 2014. 196p. Tese (Doutorado em Sociologia) - Curso de pós-graduação em Sociologia, Universidade Federal de São Carlos, São Carlos, 2014.

[14] FRITH, Simon. Performing Rites: On the Value of Popular Music. Harvard University Press, 1998.

[15] GARCIA, Rafael Marin da Silva. Moda-de-viola: lirismo, circunstância e musicalidade no canto recitativo caipira. 2011. 335p. Dissertação (Mestrado em Música) - Instituto de Artes. Universidade Estadual Paulista, São Paulo, 2011.

[16] GILROY, Paul. The Black Atlantic: Modernity and Double-Consciousness. Cambridge, Mass.: Harvard University Press, 1993.

[17] MENDÍVIL, Julio and Christian Spencer Espinosa. Made in Latin America: Studies in Popular Music. Routledge, 2015.

[18] MIDDLETON, Richard. Studying Popular Music. Open University Press, 1990.

[19] LIMA, Rossini Tavares de. Moda-de-viola: poesia de circunstância. São Paulo: Secretaria do Estado da Cultura, 1997.

[20] SANT'ANNA, Romildo. A moda é viola: ensaio do cantar caipira. São Paulo: Arte \&Ciência; Marília, SP: Ed. UNIMAR, 2000.

[21] ULHÔA, Martha Tupinambá de. Made In Brazil: Studies In Popular Music. Routledge, 2014

[22] ZAMBONI, José Carlos. O cantador do Rio Bonito: estudo sobre a poesia caipira. 1987. 225p. Dissertação (Mestrado em Letras) - Faculdade de Ciências e Letras. Universidade Estadual Paulista, Assis, 1987. 